How to cite this article:

Octavia, A., Zulfanetti., Amir, A., Sriayudha, Y., \& Amri, A. D. (2019). Entrepreneurial orientation and consumer engagement: The impact of business performance on small and medium entreprises of halal food. Malaysian Management Journal, Vol. 23(December), 87-97.

\title{
ENTREPRENEURIAL ORIENTATION AND CONSUMER ENGAGEMENT: THE IMPACT OF BUSINESS PERFORMANCE ON SMALL AND MEDIUM ENTREPRISES OF HALAL FOOD
}

\author{
ADE OCTAVIA* \\ ZULFANETTI \\ AMRI AMIR \\ YAYUK SRIAYUDHA \\ ARY DEAN AMRI \\ Faculty of Economic and Business \\ Universitas Jambi, Indonesia
}

*Corresponding author: octaviafebunja@gmail.com

\begin{abstract}
Muslim consumers nowadays are aware of the ingredients in foods thus making them more selective in choosing foods that they want to purchase and consume. Currently, there are no profiles of small and medium entreprises (SME) which have halal certificates, especially in Jambi Province. The main purpose of this research is to find the performance model of SME halal certified food. The hypotheses of this study are: (1) Entrepreneurial orientation significantly influences the consumer engagement of SME halal food (2) Entrepreneurial orientation significantly influences the entrepreneurial marketing of SME halal food(3) Entrepreneurial marketing significantly influences consumer engagement of halal food. (4) Consumer engagement significantly influences the business performance of halal food. The data for the study were collected from primary and secondary sources. Technical data collection was done through the survey sample, field observation, and
\end{abstract}


literature study. The research design uses the mixed method. Research samples comprised 250 halal food SMEs in Jambi Province, Indonesia. The data analysis technique was done using the structural equation (SEM) model and the SmartPLS 3.0 programme. The result shows a positive influence between the entrepreneurial orientation and the consumer engagement on halal food SME's business performance in Jambi Province. This study will have both managerial implications for practitioners in Indonesia as well as those in other countries and academic implications for researchers who are interested in increasing SME's business performance.

Keywords: Business performance, consumer engagement, entrepreneurial orientation, SME.

Received: 9/12/2019

Revised: 4/3/2020

Accepted: 10/3/2020

\section{Introduction}

The definition of small and medium entreprises (SMEs) in each country is usually constrained by the amount of labour or the amount of assets owned (Fard \& Amiri, 2018). This phenomenon is characterised by several companies which is achieving success in entrepreneurship. The orientation of entrepreneurship and its relationship to business performance has been an interesting topic of research in last decades. Entrepreneurial orientation is an activity that uses product innovation, takes risks and strives to proactively innovate with the goal of defeating competitors. Most SMEs do not yet have an entrepreneurial orientation as a culture and sublime values their business as SMEs. Most of them neglected in receiving assistance from the government. This is one of the SMEs difficulties to improve business performance. Some studies have been done on market orientation relationship and the SMEs business performance, but the evaluation of entrepreneurial marketing in SMEs in Indonesia has not been done much. Marketing is one of the classic problems faced by SMEs in addition to capital, information and technology mastery, and management capabilities. There is a positive influence on the market orientation to business performance (Ali \& Suleiman, 2016).

In worldwide, Muslim consumers are aware of the ingredients in food thus making them selective in choosing the food they want to consume. The majority of Indonesians are adherent to the Islamic religion which strictly regulates the halal food to be consumed. Even the need and demand for halal food is very high but only 10 percent of SMEs in Indonesia already has the halal certificate from Indonesia Islamic Council. The culinary business is still 
a favourite among people and widely used as a type of business by SMEs. Market potential and modern retail entry access are very wide open when it is a halal food product. The resellers' confidence level is also very high to receive and market SMEs' products in modern retail if they have halal certification. Al Mamun, Kumar, Ibrahim and Yusoff (2017) found that strong bonds and strong confidence of consumers to a product are intermediate factors between the entrepreneurship orientation, market orientation and SME performance. Fard and Amiri (2018) observed that halal food is not only consumed by Muslims but also the non-Muslims. This evidence suggests that Muslims and non-Muslims accept halal certificate as an opportunity for SMEs to compete in the global market. Eating is an important necessity for people. In choosing the food to consume, most consumers prioritize the taste of food and less care for its halal. Consumers will look for products that suit their needs and edible. Mohayidin and Kamarulzaman (2014) concluded that consumers' buying decisions to buy food and beverage are influenced by their religion and culture. In Islam, the foods they consume must be halal or permissible according to the Islamic principles. SMES should be able to compete to seize existing markets and get the consumers' trust. Tight competition among halal food business will continue to increase in the future.

Research on entrepreneurship has been conducted since 1930, covering concepts, forms and approaches. The focus of entrepreneurial research can be grouped on the development of concepts, testing relationships between variables and their impact on achieving business objectives. Ngui, Songan and Hong (2008) reported that the entrepreneurial orientation is the main construct of entrepreneurship and is an important factor for SMEs to improve their business performances. Entrepreneurial orientation is a moderating variable of competency orientation and SME business performance (Ibiduni, Atolagbe, Olokundun, Oke \& Amaihan, 2018). The stronger the SME's entrepreneurial orientation is, the higher the business performance can be achieved. Although some of the weaknesses mentioned are considered constraints to improve the business performance of SMEs, an entrepreneurial orientation is going to be the construct key to form the entrepreneurial ability in SMEs in Indonesia.

Therefore, it is necessary to design some strategies and effective approaches in the marketing of halal food. Once the products are halal to consume, there is attachment within consumer engagement, and it is one of the factors for the marketing success of halal food SMEs. Attachment creates an emotional condition to a specific relationship between a person and a particular object including food and beverage preference. Emotionally, a strong bond 
will encourage a person to always be close through a recurring purchase. Obvious, this hypothesis requires further testing. Based on the explanation, the problem posed in this article is closely related to obtaining the business performance of SME halal-stringed food in order to analyse whether there is a positive influence between the entrepreneurial orientation, entrepreneurial marketing and consumer attachment. The conceptual model of business performance of halal food in Jambi Province is still needed to be investigated.

\section{Research Model}

The research model as shown by Figure 1 describes the relationship between the entrepreneurial orientation, entrepreneurial marketing, consumer engagement and business performance in SMEs. The results are discussed along with the theoretical and managerial implications of the findings.

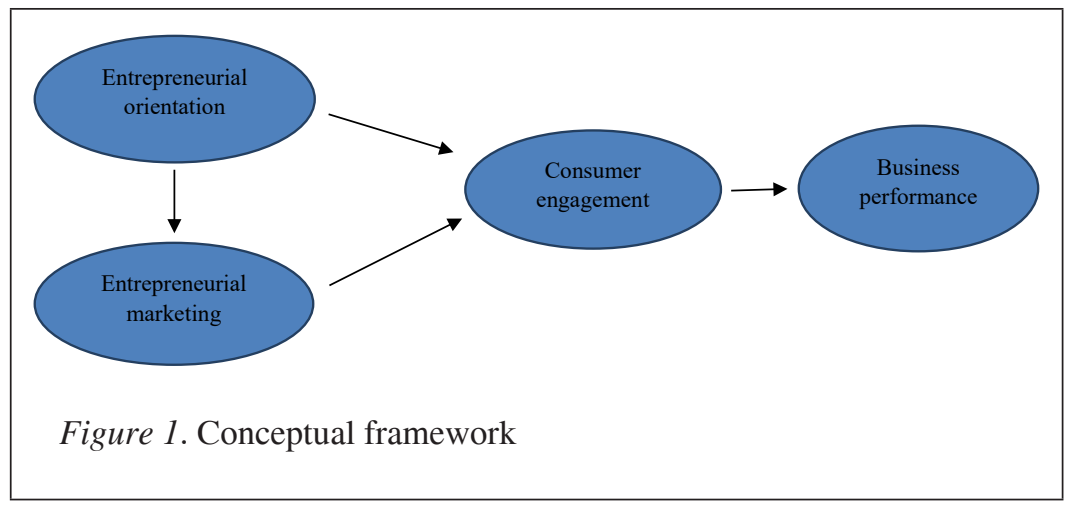

Entrepreneurial orientation is predicted to have a significant influence to consumer engagement and entrepreneurial marketing. Consumer engagement of SMS halal food is predicted to have a significant influence to business performance. Thus, the hypotheses of this study are:

$\mathrm{H}_{1}$ : Entrepreneurial orientation significantly influences consumer engagement.

$\mathrm{H}_{2}$ : Entrepreneurial orientation significantly influences entrepreneurial marketing.

$\mathrm{H}_{3}$ : Entrepreneurial marketing significantly influences consumer engagement.

$\mathrm{H}_{4}$ : Consumer engagement significantly influences business performance. 


\section{Methodology}

This research is descriptive quantitative research with a sample survey approach and observation. The survey approached is used to measure symptoms and help to compare that with the predetermined criteria. The number of samples was 250 respondents. The sample is chosen from different various of SMEs in Jambi Province in 2019. The sample was randomly drawn from the population of SMEs which sell halal food certified within the area of Jambi Province in Indonesia. This type of field includes explanatory research. Related to the hypotheses, the analytical tool used is partial least square (PLS). This measurement with Smart PLS uses the outer model and inner model. Evaluation of the measurement model of the outer model is done using loading factor value, average variance extracted (AVE), composite reliability value, and the Cronbach's alpha value.

\section{Results and Discussion}

A total of 250 respondents participated in the study. The respondents consist of SMEs with various types of certified and not-certified business from Indonesian Islamic Council in Jambi Province. An important function of Indonesian Islamic Council is to provide halal-certificate for food and drink which is produced in Indonesia. The sample was selected randomly. Table 1 shows that there were more uncertified halal food SMEs (55.2\%) respondents than the certified halal food SMEs $(44.8 \%)$ respondents involved in this research. The highest percentage fell under the age group of below 31 years old (43.2\%). The majority of respondents were in Senior High School Level education $(62.4 \%)$. The results also reveal the most top position among the respondent in SMEs, which is, as a founder as well as owner of the organisation (71.2\%), the number of employees, which is less than five persons (75.6\%) for each SME and the respondents whose experience in SMEs was less than five years $(49.6 \%)$.

Table 1

Profile of Respondents

\begin{tabular}{lcc}
\hline & Characteristic & Percentage \% \\
\hline Halal certification & Certified & 44.8 \\
& Uncertified & 55.2 \\
Age & Less than 31 years & 43.2 \\
\hline & & (continued)
\end{tabular}




\begin{tabular}{llc}
\hline & Characteristic & Percentage \% \\
\hline $31-35$ years & 24.4 \\
$36-40$ years & 16.4 \\
Less than 40 years & 16.0 \\
Bachelor/degree & 18.4 \\
Level of education & Senior High & 62.4 \\
Junior High & 12.4 \\
Elementary & 5.6 \\
Uneducated & 1.2 \\
Oosition in SMES & Ewner and founder & 71.2 \\
Employee & Less than 5 employee & 28.8 \\
& $6-10$ employee & 75.6 \\
& More than 10 employee & 15.6 \\
& Less than 5 years & 8.8 \\
5 - 10 years & 49.6 \\
More than 10 years & 38.8 \\
\hline
\end{tabular}

Table 2 shows the score of measurement for each dimensions. The results of Cronbach's alpha, composite reliability and average variance extracted score were explained clearly.

Table 2

\section{Measurement Model}

\begin{tabular}{lccc}
\hline & Cronbach's alpha & $\begin{array}{c}\text { Composite } \\
\text { reliability }\end{array}$ & $\begin{array}{c}\text { Average variance } \\
\text { extracted (AVE) }\end{array}$ \\
\hline Business performance & 0.832 & 0.872 & 0.581 \\
Consumer engagement & 0.795 & 0.879 & 0.709 \\
Entrepreneurial orientation & 0.722 & 0.807 & 0.377 \\
Entrepreneurial marketing & 0.685 & 0.791 & 0.394 \\
\hline
\end{tabular}

The entire variables in this study satisfy the criteria of the composite reliability value which is above 0.7 . The consumer engagement variable has the highest score. It means that the construction of this research has good 
reliability. For Cronbach's alpha parameter, all of variables in this study have the value exceeding 0.6 and the business performance has the highest score. This result shows all those variables meet the measurement criteria. Furthermore, for the AVE analysis, the results of business performance and consumer engagement also have the AVE value above 0.5 . This means that both variables met the measurement criteria. While the entrepreneurial orientation and entrepreneurial marketing have AVE scores below 0.5, this means the proposed model needs to be supported by more complete data.

Table 3

\section{Structural Model}

\begin{tabular}{|c|c|c|c|c|c|}
\hline Hypothesis & $\begin{array}{l}\text { Original } \\
\text { sample }\end{array}$ & $\begin{array}{c}\text { Sample } \\
\text { mean }\end{array}$ & $\begin{array}{l}\text { Standard } \\
\text { deviation }\end{array}$ & $t$ - stat & Conclusion \\
\hline $\begin{array}{ll}\mathrm{H}_{1}: & \begin{array}{l}\text { Entrepreneurial orientation } \rightarrow \\
\text { Consumer engagement }\end{array}\end{array}$ & 0.235 & 0.251 & 0.121 & 1.939 & unsupported \\
\hline $\begin{array}{ll}\mathrm{H}_{2}: \quad \begin{array}{l}\text { Entrepreneurial orientation } \rightarrow \\
\text { Entrepreneurial marketing }\end{array}\end{array}$ & 0.615 & 0.638 & 0.061 & 9.969 & supported \\
\hline $\begin{aligned} \mathrm{H}_{3}: & \begin{array}{l}\text { Entrepreneurial marketing } \rightarrow \\
\text { Consumer engagement }\end{array}\end{aligned}$ & 0.118 & 0.123 & 0.132 & 0.897 & unsupported \\
\hline $\mathrm{H}_{4}: \begin{array}{c}\text { Consumer engagement } \\
\text { Business performance }\end{array} \rightarrow$ & 0.389 & 0.415 & 0.077 & 5.023 & supported \\
\hline
\end{tabular}

As shown in Table 3, the first hypothesis was performed to investigate the impact of entrepreneurial orientation on consumer engagement on SMEs. It predicts that the entrepreneurial orientation has significant effect on consumer engagement. The finding of the study, shows that hypothesis 1 was not significant in determining entrepreneurial orientation to consumer engagement of halal food in SMEs. It was specified based on the first proposed hypothesis. The result shows that $t$-statistic value is less than 1.96. Its means that the hypothesis 1 was not supported. Entrepreneurial orientation of halal food SME is not directly affecting the consumers but it is directly affecting the internal management of SME itself. Covin and Slevin (1991) proposed that the entrepreneurial orientation of SME engaged in relatively high levels of innovative, proactive, and risk-taking, behaviours. Moreover, the innovativeness dimension of entrepreneurial reflects the tendency to engage in and support new idea generation, novelty, experimentation, and creative processes. Innovative firms, through the creation and introduction of 
new products and technologies, develop a market niche with new products/ services, differentiate themselves and/or substitute incumbents with better quality, cheaper price or other means that customers value (Richard, Wu \& Chadwic, 2009).

Hypothesis 2 predicts that entrepreneurial orientation significantly related to the entrepreneurial marketing. The hypothesis 2 is proven and supported by the study which shows that there is a significant positive relationship between the entrepreneurial orientation and entrepreneurial marketing $(t$-statistic $=9.969)$. The recorded positive relationship implies that as SMEs put emphasis on pro-active, risk taker and competitive aggressiveness behaviour, they exploit opportunities before competitors to build competitive advantage and take bold steps to defend created advantage through competitive aggressiveness. It suggests that in SMEs halal certified food where new opportunities are opening up, a pro-active posture is more relevant for timely seizure of emerging opportunities. Competitive aggressive posture and the risk-taker chance may give advantage to SMEs to defend their competence from rivals, which is important in the open entrepreneurial marketing. Le Roux and Bengesi (2014) reported that the open market environment in developing economies, where rivals are free to enter and leave the business environment, the understanding of competitive aggressiveness, pro-activeness and risktaking behaviour of firm is crucial to explain the SME performance.

Hypothesis 3 predicts that there is a relation between entrepreneurial marketing and consumer engagement. The result shows that there is no significant relationship between both of them since $t$-statistic is less than 1.96. Thus, it can be concluded that the hypothesis 3 is unproven. Consumer engagement is concerned more with affective passion, affection, and connection between its consumer and products or services. Whalen and Akaka (2016) observed that the development of entrepreneurial marketing has led to a focused interest on understanding the importance of the market phenomena at the intersection of entrepreneurship and marketing. Additional emphasis on opportunities is important for entrepreneurial marketing researchers because opportunities are the central focus in the study of entrepreneurship, and in this study entrepreneurial marketing does not relate significantly to consumer engagement .

Hypothesis 4 predicts that there is a relationship between the consumer engagement and business performance. The result proves that there is a significant relationship between both two variables $(t$-statistic $=5.023)$. Thus, hypothesis 3 is proven and supported by the data, that is, risk-taking behaviour is likely to promote pro-active initiatives necessary for firms to 
attain high performance. Le Roux and Bengesi (2014) observed that it is consistent with the previous studies in developed economies and suggested that pro-active behaviour is associated with high risk-taking behaviors. These findings may suggest that in emerging economies, risk-taking behaviour is necessary to promote pro-active behaviours for SMES to take advantage of the emerging opportunities. The stronger engagement between consumers and firms, the higher the business performance of the firms. Mc Dowel, Haris and Zhang (2009)reported that there are several factors that make up the business performance. These are trust, dependency, information about product quality, and the ability to continuously improve quality. The term 'performance' of the term 'job performance' or 'actual performance' (work achievement or actual achievement achieved by a person) is the result of work in quality and quantity achieved by an officer in carrying out his or her duties in accordance with the responsibilities given. In general, performance is differentiated into two, namely, the individual performance and organisational performance. Performance is about doing the work and results achieved from the work. Performance is all about what to do and how to work on it. Moreover, the result is shown fully in the following bootstrapping model (Figure 2) of this study:

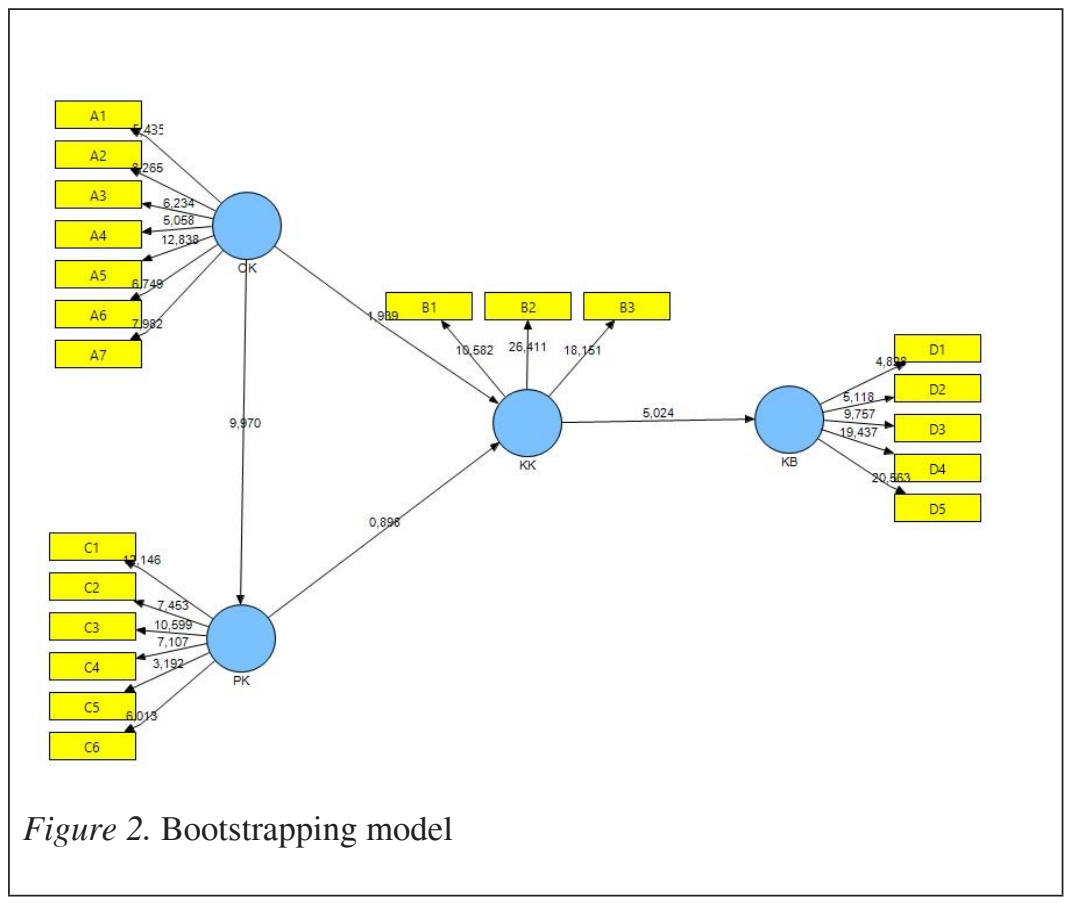




\section{Conclusion}

Halal food is a certification system that audits products fit with Islamic principles not only the food product but also cosmetics, finance and logistic. Although most of its population is Muslim, Indonesia still lacks the number of SMEs with halal food certificate. This study reported that there is positive and significant relationship between the entrepreneurial orientation and consumer engagement. Thus, consumer engagement is also significantly related to the business performance and the halal food of SMEs in Jambi Province Indonesia. On the other hand, entrepreneurial is not significantly related to the consumer engagement and the entrepreneurial marketing is not significantly related to the consumer engagement of halal food SMEs in Jambi Province. Neverless, having a certified halal label will be an advantage for the SMES in order to attract more Muslim consumers to purchase. Thus, greater efforts should be made by the government and also the Indonesian Islamic Council (MUI) to improve the knowledge and awareness of SMEs to provide halal food products in the market.

\section{Acknowledgements}

This research was conducted based on the funding received from University of Jambi through The Institute of Research and Community Service of University of Jambi, Indonesia.

\section{References}

Ali, M. H., \& Suleiman, N. (2016). Sustainable food production: Insights of Malaysian halal small and medium sized entreprises. International Journal of Production Economics, 181, 303-314.

Al-Mamun, A., Kumar, N., Ibrahim, M. D., \& Yusoff, M. N. (2017). Validating the measurement of entrepreneurial orientation. Economics and Sociology, 10(4), 51-66.

Covin, J. G., \& Slevin, D. P. (1991). Entrepreneurial versus conservative firms: A comparison of strategies and performance. Journal of Management Studies, 28, 439-462.

Fard, M. H., \& Amiri, N. S. (2018). The effect of entrepreneurial marketing on halal food SMEs performance. Journal of Islamic Marketing, 9(3), 598-620.

Ibiduni A. S., Atolagbe, O. J., Olokundun, M. A., Oke, O. A., \& Amaihan, A. B. (2018). Moderating effect of entrepreneurial orientation on entrepreneurial competencies and performance of agro based SMEs. International Journal of Entrepreneurship, 22(2) 55-62. 
Le Roux, I., \& Bengesi, K. M. K. (2014). Dimensions of entrepreneurial orientation and small and medium enterprise performance in emerging economies. Development Southern Africa, 31(4), 606-624.

Mc Dowell, W. C., Harris, M. L., \& Zhang, L. (2009). Relational orientation and performance in micro business and small and medium-sized entreprises: An examination of inter organizational relationships. Journal of Business and Entrepreneurship, 21(2),

Mohayidin, M. G., \& Kamarulzaman, N. H. (2014). Consumers' preferences toward attributes of manufactured halal food products. Journal of International Food \& Agribusiness Marketing, 26(2), 125-139.

Ngui, K. S., Songan, P., \& Hong, K. S. (2008). Organizational learning capability of Malaysia SMEs: Examining the effect of entrepreneurial orientation and human-capital development practices. Journal of Information \& Knowledge Management, 7(4), 219-230.

Ricard, O. C., Wu, P., \& Chadwic, K. (2009). The impact of entrepreneurial orientation on firm performance: The role of CEO position tenure and industry tenure. The International Journal of Human Resource Management, 20(5), 1078-1095.

Whalen, P. S., \& Akaka, M. A. (2016). A dynamic market conceptualization for entrepreneurial marketing: The co-creation of opportunities. Journal of Strategic Marketing, 24(1), 61-75. 